\title{
Trust Versus Perceived Quality in Scholarly Publishing: A Personality- Attitude-Intention Approach
}

\author{
Lars Moksness and Svein Ottar Olsen
}

\begin{abstract}
Researchers at UiT-The Arctic University of Norway studied how agreeableness and conscientiousness influence trust and perceived quality and how these factors subsequently impact the intention to publish research articles via open access (OA) or non-OA channels. The main findings show that, while trust increases intention to publish via $O A$, it decreases intention to publish via non-OA channels. Indicators of perceived quality, on the other hand, exert a positive influence on the intention to publish via non-OA, while decreasing the intention to publish non-OA. The results suggest that trust is pivotal in increasing publishing via $O A$.
\end{abstract}

\section{Introduction}

Digital academic journals serve as the main dissemination method for peer-reviewed research articles. These journals can be divided into two main categories: open access $(\mathrm{OA})$ and non-open access (non-OA) journals. OA literature is defined by Suber as "digital, online, free of charge, and free of most copyright and licensing restrictions." ${ }^{1}$ The reasons why no-cost OA adoption is slow-going are still largely unexplored, both theoretically and empirically. However, some influential reasons are suggested in the literature: uncertainty or distrust and perceived lower quality or reputation. ${ }^{2}$ Distrust can be caused by general skepticism toward new publication technologies and journals, article processing charges (APC), predatory publishers, and low impact factor. ${ }^{3}$ Distrust aside, findings by Björk and Salomon indicate that OA literature is approaching the same quality or academic impact as non-OA literature, in addition to maintaining a citation advantage. ${ }^{4}$ To our knowledge, no previous research has tested how researchers' trust and perceived quality interact to influence both OA and non-OA publishing in one integrated study.

Another interesting question to explore is what explains differences in scholars' trust and beliefs about perceived quality of publication outlets. The study of interpersonal differences in personality has received increased attention over the recent years, including how personality traits influence scientific creativity, technology acceptance,

* Lars Moksness is a PhD candidate at the School of Business and Economics and University Library at UiT-The Arctic University of Norway; e-mail: lars.moksness@uit.no. Svein Ottar Olsen is a professor of marketing at the School of Business and Economics at UiT-The Arctic University of Norway; e-mail: svein.o.olsen@uit.no. (02018 Lars Moksness, Svein Ottar Olsen, Attribution-NonCommercial (http:// creativecommons.org/licenses/by-nc/4.0/) CC BY-NC. 
and trust in new technology. ${ }^{5}$ However, research on how researchers interact with and use digital publishing at the individual level is somewhat limited.

The main purpose of this study is to contribute a deeper understanding of the determinants of OA and non-OA publishing. We consider contemporary scholarly publishing as a special case of information technology adoption, a perspective employed in previous research as well. ${ }^{6}$ More precisely, we first examine whether and how trust in OA publishing and perceived journal quality influence the intention to publish research articles (OA and non-OA). Second, this study explores how the two general personality traits of agreeableness and conscientiousness influence trust and perceived quality in an integrated model tested within a latent constructs structural modeling approach. ${ }^{7}$ The structural model with hypotheses, as presented in this article, was tested on a sample of 295 researchers at a Norwegian university.

\section{Literature Review}

The most influential predictor of a given behavior is an individual's intention toward performing that behavior. Intention is defined as a measure of effort and willingness to perform a behavior and is frequently used as the ultimate dependent variable in behavioral studies, including some research on OA publishing. ${ }^{8}$ The causal relationship is based on traditional attitude theory, where intention is determined by attitudes such as perceptions of quality and trust, which in turn are influenced by personality traits. ${ }^{9}$ A person's intention encompasses both the direction and the strength of the motivation to engage in a behavior. Intention is consistently found to predict a range of different behaviors and is reported to explain an average of 28 percent $\left(R^{2}=0.28\right)$ of the variance in behavior. ${ }^{10}$ Dulle and Minishi-Majanja report similar explanatory power, as do Khalili and Singh $\left(R^{2}=0.27\right.$ and 0.22 , respectively) in intention to publish in OA journals. ${ }^{11}$

When considering a publication venue, several factors are thought to influence scholars' intentions. These may concern the presence or absence of publishing fees (that is to say, APC), trustworthiness, reliability, impact, or the access type (OA/ non-OA) associated with a journal. ${ }^{12}$ The belief that a journal conducts its business with honesty and integrity and that published articles are trustworthy are important considerations researchers take into account prior to selecting an outlet. Trust, then, is a crucial component in overcoming perceptions of uncertainty and risk in a digital publishing environment. ${ }^{13}$ Other important factors pertain to the properties of the journal, including its reputation, perceived quality, impact factor, acceptance rate, citation rate, visibility, and the status and prestige associated with publishing in the journal. ${ }^{14}$ For example, Watkinson and colleagues cite pressure to publish (to secure promotion and tenure) as an important reason for journal selection based on the impact factor, ${ }^{15}$ given that publishing in a journal with high impact is assumed to be a mark of quality and prestige. ${ }^{16}$

There is general agreement that personality traits can be grouped in five dimensions: openness, conscientiousness, extraversion, agreeableness, and neuroticism. ${ }^{17}$ Researchers are, in some instances, found to score differently from nonresearchers on the specific dimensions we include in our study. For our purposes, we define researchers as people who conduct academic research. The personality dimensions include conscientiousness, or the quality of being careful, cautious, calculating, and self-controlled, and openness, which includes creativity and being open to new ideas. ${ }^{18}$ However, the disposition to trust is likely deeply rooted in a different trait, and studies on agreeableness suggest that a person who is agreeable is also trusting, tolerant, and honest, indicating a stronger relation to a trusting disposition than openness. ${ }^{19}$ This implies that a trait that is not necessarily associated with being predominant in researchers could still prominently influence trust. Conscientiousness, on the other 


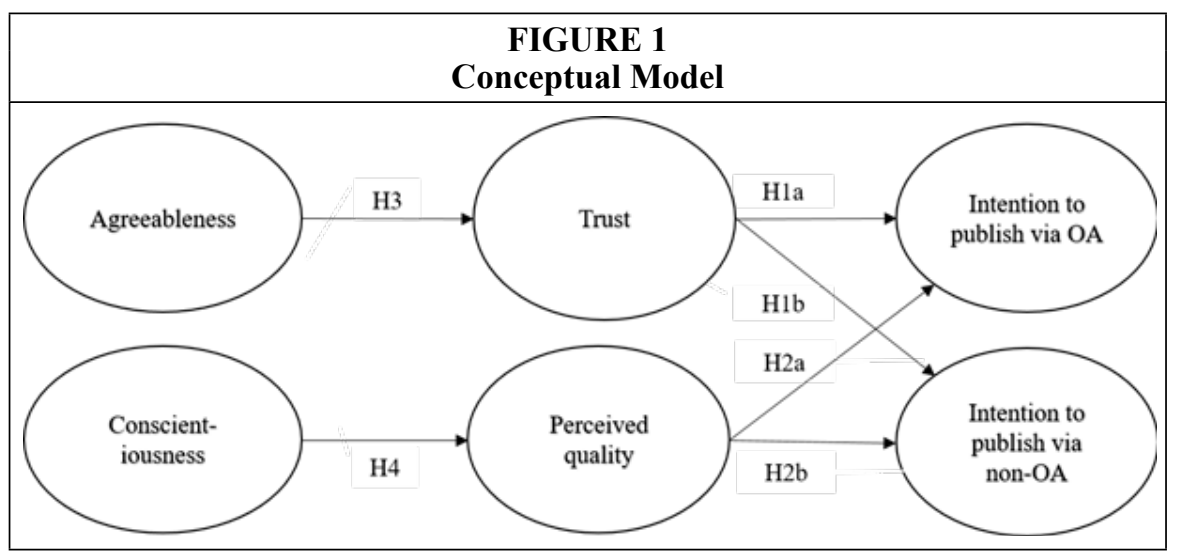

hand, appears to be a strong candidate for directly impacting perceived quality, given that it is generally a trait of one who is task- and goal-directed. ${ }^{20}$ Conscientiousness is, for example, strongly linked to early academic achievement, ${ }^{21}$ a crucial first step on the path to a career as a researcher. We will explore the theoretical constructs (see figure 1) in more detail in the following sections.

The criteria employed by researchers when selecting an outlet to publish research can be grouped in two broad categories: trust and perceived quality. ${ }^{22} \mathrm{~A}$ widely accepted definition of trust is ventured by Mayer, Davis, and Schoorman, whereby trust is "the willingness of a party to be vulnerable to the actions of another party based on the expectation that the other will perform a particular action to the trustor, irrespective of the ability to monitor or control that other party." ${ }^{23}$ Empirically, we can operationalize this as indicators that relate to the benevolence, competence, and integrity of the journal and its content. ${ }^{24}$ Thus, in this study we define trust as researchers' evaluation of the integrity and competence of OA and non-OA articles and outlets. Perceived quality is defined as the criteria that researchers deem important when selecting a publication outlet. They are conceptualized as representing properties of the journal, such as impact factor, elevated status associated with publishing in the journal, and perceived overall quality. Within our framework, trust and perceived quality are hypothesized to act as direct determinants of intention to publish research articles through OA or non-OA.

An influential and potentially misleading proxy for quality is the journal impact factor. ${ }^{25}$ It prevails as an indicator of academic merit and value, ${ }^{26}$ though there are more appropriate measures of article impact and journal ranking. ${ }^{27} \mathrm{~A}$ high-impact factor is often blindly accepted as describing a journal's quality, and publishing in a highimpact journal bestows status upon the published authors. However, Tenopir and her colleagues report that researchers perceive the impact factor to be of less importance than, for example, whether an article is properly peer-reviewed.$^{28}$ Notwithstanding, the need for a fast and easy metric to ascertain quality in a world where there are more than a million articles published each year has led to the adoption of the impact factor as a measure anybody can interpret. ${ }^{29}$ Even though it is broadly used for a purpose for which it was never intended, it remains a good indicator of researchers' publishing intentions and, in concert with status and quality, is expected to play a major part in researchers' publishing intentions. Thus, in this study we hypothesize that:

H1a: Trust has a significant and positive effect on the intention to submit articles to OA journals. 
$\mathrm{H} 1 \mathrm{~b}$ : Trust has a significant and negative effect on the intention to submit articles to non-OA journals.

H2a: Perceived quality has a significant and negative effect on the intention to submit articles to OA journals.

$\mathrm{H} 2 \mathrm{~b}$ : Perceived quality has a significant and positive effect on the intention to submit articles to non-OA journals.

Situational demands also influence which personality trait, or traits, may be most prominent in affecting intentions or behavioral outcomes. For example, conscientiousness (being careful, cautious, calculating, and self-controlled) is identified as an important predictor of job performance, and in some studies, as reported by Feist, researchers are found to score higher on conscientiousness than nonresearchers. ${ }^{30} \mathrm{~A}$ conscientious researcher favors planning and dependability, ${ }^{31}$ suggesting that this trait will be most prominent when evaluating "traditional" indicators of publishing intentions such as impact factor and status. We should note that Feist's meta-analysis is sometimes criticized for using too wide a definition of the term "scientist"; it included anybody from junior high school through adulthood who "showed a special talent in science, majored in science, or [who] worked professionally in science. ${ }^{132}$ Other studies report that researchers score lower on conscientiousness compared to nonresearchers. ${ }^{33}$

Furthermore, agreeableness (being trusting, tolerant, and honest), but not conscientiousness, is found to have a significant effect on trust. ${ }^{34}$ An agreeable researcher can be considered trusting, amiable, and cooperative, which suggests a predisposition to assume a more favorable stance toward a publication model that resonates with this trait. ${ }^{35}$ Indeed, studies show that agreeableness is linked to an increased intention to share knowledge among researchers, and agreeable personalities are more inclined to focus on the cooperative aspects when evaluating a new technology. ${ }^{36}$

Although personality is not widely investigated in relation to electronic publishing, it has been extensively researched in relation to adoption and use of IT and the Internet. For example, there is evidence that agreeableness is related to beliefs about the usefulness of a mobile service $(r=0.42)$ and trust in the provider $(r=0.44)$, a sentiment signaling a favorable disposition to the expected usefulness of information technology. ${ }^{37}$ Conscientiousness, on the other hand, underpins the processing of factors related to perceived and actual IT system use $(r=0.21)$, which is oriented toward the benefit of using technology. ${ }^{38}$ Consequently, agreeableness ought to be the most influential personality trait when evaluating trust-related indicators of OA/non-OA, while conscientiousness should unilaterally affect perceived quality. Although no hypothesized effect is expected, the paths from agreeableness to perceived quality and conscientiousness to trust will be tested to verify nonsignificance. Thus, the personality traits of agreeableness and conscientiousness are hypothesized to influence the factors of trust and perceived quality, and we may formulate the following hypotheses:

H3: Agreeableness has a significant and positive effect on trust.

H4: Conscientiousness has a significant and positive effect on perceived quality.

\section{Research Methodology}

A sample of researchers at UiT-The Arctic University of Norway-completed a questionnaire measuring personality traits, publishing intentions, and trust and perceived quality of publication venues. UiT is the third largest university in Nor- 
way and the northernmost university of the world. It employs approximately 3,000 academic and administrative staff and has 15,500 students, more than 20 percent of whom are international. An invitation to participate in the survey was sent via e-mail to 2,971 employees, and respondents followed a link to the questionnaire. A total of 322 respondents completed the survey. An online surveying tool (Questback) was used to distribute the questionnaire (see appendix) and collect the data. The data were analyzed using IBM SPSS and AMOS. The sample consisted of researchers across all disciplines who had published, or were intending to publish, peer-reviewed articles. Prior to analysis, the data set was screened for missing data and outliers, resulting in the deletion of 27 respondents from further analysis. The remaining sample consisted of 295 researchers.

The measures in this study, with the exception of perceived quality, are based on previously validated measures adapted to our research context. Intention of a researcher to publish (OA/non-OA) was assessed according to recommendations by Fishbein and Ajzen and adapted to the context of scholarly publishing. ${ }^{39}$ All items are listed in table 1. Intention was measured on a 7-point scale, where 1 indicates disagreement and 7 indicates agreement. Sample items are: "My goal is to submit the majority of my future research articles to open access journals (OA)" and "I plan to submit the majority of my future research articles to non-open access journals (non-OA)."

The trust scale was developed based on the work of McKnight, Choudhury, and Kacmar, and measured by three items on a 7-point scale ranging from "totally disagree" to "totally agree." 40 The items assessed an individual's perception of the trustworthiness, honesty, and reliability of OA and non-OA publications (articles and journals). A sample item is "Overall, articles published in non-open access journals are more reliable than articles published in open access journals."

The perceived quality scale consisted of items adopted from the broader literature on publishing and measured on a 7-point scale. ${ }^{41}$ Respondents read the statement "Please state to what degree the following factors are important when choosing where to publish research articles" and were encouraged to indicate level of importance (very unimportant-very important) of perceived quality criteria (such as impact factor of journal). These indicators have been previously found to influence publishing intentions. ${ }^{42}$

Agreeableness and conscientiousness were measured by items from the short Big Five Inventory (BFI-S), which is a measure based on the "Big Five" factor structure. ${ }^{43}$ The BFI-S is measured on a 7-point scale (three indicators per factor). Respondents read the statement "I see myself as someone who..." and subsequently indicated level of agreement with a statement such as "...does things efficiently" (conscientiousness) and "...has a forgiving nature" (agreeableness). Short measures of personality are frequently used and maintain adequate reliability levels across studies, while trading off some accuracy in favor of speed. ${ }^{44}$ All items are presented in table 1.

In this study, we use a latent variable structural equation modeling (SEM) approach. Mackenzie states that the advantages of using this method include "the ability to control for measurement error; the ability to test complex theoretical structures; and more powerful ways to assess measure reliability." 45 SEM models consist of two major components: a measurement model, which connects the indicators to the latent factors, and a structural model, which connects the constructs to other constructs. The procedure starts with running a confirmatory factor analysis (CFA) to ascertain construct validity. This is followed by a structural analysis using maximum likelihood estimation (MLE) to test the hypotheses. To ascertain how well the model fits the data, several fit indices are reported. These include the normed chi-square (CMIN/DF), where the value should be less than 5; the comparative fit index (CFI), where the value should exceed .90, the closer to 1 the better; the Tucker 
Lewis index (TLI), where a value exceeding .90 is considered good; and the root mean square error of approximation (RMSEA), which should be lower than .08 to indicate a good fit. ${ }^{46}$

\section{Analysis and Results}

Construct validity of the six constructs in the measurement model (CMIN/DF $=1.94$, $\mathrm{df}=96, \mathrm{CFI}=0.95, \mathrm{TLI}=0.94$, RMSEA $=.056$ ) indicates acceptable fit, given that the values are within recommended thresholds. ${ }^{47}$ Reliability measures and factor loadings for the final solution are presented in table 1 and correlations and descriptive statistics in table 2. Reliability is indicated by the composite reliability score (CR) and the value should ideally exceed .70. Discriminant validity is established by ascertaining whether the value of the square root of the average variance extracted (AVE) for each construct exceeds the value of the interconstruct correlations. ${ }^{48}$ These numbers are displayed in bold in table 2 .

Loadings in table 1 show that most values are significant and range from approximately 0.60 to 0.94 , indicating an acceptable convergent validity of the constructs. However, the reversed personality indicators, particularly within the agreeableness factor, failed to reach this mark. Deleting the offending item from agreeableness, but not conscientiousness, resulted in acceptable levels of CR and AVE. Model fit is also improved (CMIN/ $\mathrm{DF}=1.77, \mathrm{df}=75, \mathrm{CFI}=0.97, \mathrm{TLI}=0.95, \mathrm{RMSEA}=.051)$. The $\mathrm{CR}$ and AVE scores mostly exceed the acceptable thresholds of 0.70 and 0.50 for intention, trust, and perceived quality. Conscientiousness falls below these thresholds, likely due to the reversed item.

\begin{tabular}{|c|c|c|c|}
\hline \multicolumn{4}{|c|}{$\begin{array}{c}\text { TABLE } 1 \\
\text { Standardized Confirmatory Factor Analysis Coefficients And Construct } \\
\text { Reliability }\end{array}$} \\
\hline Constructs and Indicators & $\begin{array}{l}\text { Factor } \\
\text { Loadings }\end{array}$ & $\begin{array}{l}\text { Composite } \\
\text { Reliability }\end{array}$ & $\begin{array}{l}\text { Variance } \\
\text { Extracted }\end{array}$ \\
\hline Intention to publish via open access & & .84 & .84 \\
\hline $\begin{array}{l}\text { My goal is to submit the majority of my future } \\
\text { research articles to open access journals. }\end{array}$ & .97 & & \\
\hline $\begin{array}{l}\text { I intend to do what I can to submit the majority of } \\
\text { my future research articles to open access journals. }\end{array}$ & .91 & & \\
\hline Intention to publish via non-open access & & .81 & .67 \\
\hline $\begin{array}{l}\text { I plan to submit the majority of my future } \\
\text { research articles to non-open access journals. }\end{array}$ & .82 & & \\
\hline $\begin{array}{l}\text { My goal is to submit the majority of my future } \\
\text { research articles to non-open access journals }\end{array}$ & .81 & & \\
\hline Trust & & .83 & .63 \\
\hline $\begin{array}{l}\text { In general, I am confident the articles published } \\
\text { in open access journals are trustworthy. }\end{array}$ & .94 & & \\
\hline I would assume most open access journals are honest. & .81 & & \\
\hline $\begin{array}{l}\text { Overall, articles published in non-open access } \\
\text { journals are more reliable than articles published in } \\
\text { open access journals. (r) }\end{array}$ & 60 & & \\
\hline Perceived quality & & .74 & .49 \\
\hline
\end{tabular}




\begin{tabular}{|c|c|c|c|}
\hline \multicolumn{4}{|c|}{$\begin{array}{c}\text { TABLE } 1 \\
\text { Standardized Confirmatory Factor Analysis Coefficients And Construct } \\
\text { Reliability }\end{array}$} \\
\hline Constructs and Indicators & $\begin{array}{c}\text { Factor } \\
\text { Loadings }\end{array}$ & $\begin{array}{l}\text { Composite } \\
\text { Reliability }\end{array}$ & $\begin{array}{l}\text { Variance } \\
\text { Extracted }\end{array}$ \\
\hline \multicolumn{4}{|l|}{$\begin{array}{l}\text { (Please state to which degree the following factors } \\
\text { are important when choosing where to publish your } \\
\text { research articles.) }\end{array}$} \\
\hline Publishing (in a journal) will give me high status. & .56 & & \\
\hline Impact factor of journal. & .85 & & \\
\hline Perceived quality of journal. & .65 & & \\
\hline Agreeableness & & .71 & .56 \\
\hline \multicolumn{4}{|l|}{ (I see myself as someone who ...) } \\
\hline$\ldots$ is sometimes rude to others. $(\mathrm{r})$ & $.32 *$ & & \\
\hline$\ldots$ has a forgiving nature. & .54 & & \\
\hline$\ldots$ is considerate and kind to almost everyone. & .92 & & \\
\hline Conscientiousness & & .65 & .39 \\
\hline ... does a thorough job. & .62 & & \\
\hline$\ldots$ tends to be lazy. (r) & .52 & & \\
\hline$\ldots$ does things efficiently. & .71 & & \\
\hline
\end{tabular}

Table 2 displays the correlation matrix for the constructs in the hypothesized model and shows that approximately half of the correlations are significant at the $P<.001$ level and below 0.70. A nonsignificant relationship is detected between agreeableness, conscientiousness, and intention (OA/non-OA). A nonsignificant relationship between agreeableness and perceived quality, and conscientiousness and trust, is expected.

\begin{tabular}{|l|c|c|c|c|c|c|c|c|}
\hline \multicolumn{10}{|c|}{ Correlation Matrix and Descriptive Statistics } \\
\hline \multicolumn{1}{|c|}{ N= 295 } & Mean & SD & $\mathbf{1}$ & $\mathbf{2}$ & $\mathbf{3}$ & $\mathbf{4}$ & $\mathbf{5}$ & $\mathbf{6}$ \\
\hline 1. Intention OA & 4.21 & 1.76 & $\mathbf{0 . 9 2}$ & & & & & \\
\hline 2. Intention non-OA & 3.01 & 1.56 & $-0.76^{* *}$ & $\mathbf{0 . 8 2}$ & & & & \\
\hline 3. Trust & 4.59 & 1.38 & $0.57^{* *}$ & $-0.49^{* *}$ & $\mathbf{0 . 7 9}$ & & & \\
\hline 4. Perceived quality & 4.87 & 1.21 & $-0.22^{*}$ & $0.32^{* *}$ & -0.10 & $\mathbf{0 . 7 0}$ & & \\
\hline 5. Agreeableness & 5.01 & 1.11 & 0.10 & -0.13 & $0.17 *$ & 0.05 & $\mathbf{0 . 7 5}$ & \\
\hline 6. Conscientiousness & 5.32 & 0.91 & 0.07 & -0.01 & 0.12 & $0.30^{* *}$ & $0.44^{* *}$ & $\mathbf{0 . 6 2}$ \\
\hline
\end{tabular}

Note: $* * P<.001 ; * P<.05$. Bold numbers in the diagonal indicate the square root of the average.

The theoretical model presented in figure 1 was tested using structural equation analyses (SEM). Fit indices indicate the model fits the data well (CMIN/ $\mathrm{DF}=1.72, \mathrm{DF}=82, P=.000, \mathrm{CFI}=0.97, \mathrm{TLI}=0.96, \mathrm{RMSEA}=.050)$. Test results 
are presented in table 3. In line with Hypothesis 1a, the results demonstrated that trust strengthened researchers' intention to publish OA articles $(\beta=0.56$, $z=9.88, P<.001)$. Hypothesis $1 \mathrm{~b}$ suggested there would be an opposite effect on intention to publish non-OA articles, which is also supported by the data $(\beta=-0.44, z=-7.21, P<.001)$. Consequently, both Hypotheses $1 \mathrm{a}$ and $1 \mathrm{~b}$ are confirmed.

\begin{tabular}{|l|c|c|c|c|c|}
\hline \multicolumn{7}{|c|}{ Testing Direct Effects } \\
\hline \multicolumn{1}{|c|}{ Path (N = 295) } & Hypothesis & $\begin{array}{c}\text { Standardized } \\
\text { Coefficients }\end{array}$ & P-value & z-value & Conclusion \\
\hline Trust $\rightarrow$ intention OA & H1a & $0.56^{* *}$ & .001 & $9.88^{*}$ & Supported \\
\hline Trust $\rightarrow$ intention non-OA & H1b & $-0.47^{* *}$ & .001 & $-7.21^{*}$ & Supported \\
\hline PQ $\rightarrow$ intention OA & H2a & $-0.17^{*}$ & .003 & $-2.99^{*}$ & Supported \\
\hline PQ $\rightarrow$ intention non-OA & H2b & $0.28^{* *}$ & .001 & $4.12^{*}$ & Supported \\
\hline Agreeableness $\rightarrow$ trust & H3 & $0.19^{*}$ & .013 & $2.47^{*}$ & Supported \\
\hline Cnsc. $\rightarrow$ quality & H4 & $0.27^{* *}$ & .001 & $3.20^{*}$ & Supported \\
\hline Note: $* * P<.001 ; * P<.05$ PQ $=$ perceived quality; Cnsc. $=$ conscientiousness \\
\hline
\end{tabular}

Further support is found for Hypotheses $2 \mathrm{a}$ and $2 \mathrm{~b}$, which suggests that perceived quality weakens the intention to publish OA articles $(\beta=-0.40, z=-2.99, P<.05)$, while increasing the intention to publish non-OA articles $(\beta=0.51, z=4.12, P<.001)$. Hypothesis 3 , which proposed that agreeableness increases trust, is supported by the data $(\beta$ $=0.26, z=2.47, P<.05)$. Finally, conscientiousness has a positive effect on perceived quality, confirming hypothesis $4(\beta=0.25, z=3.19, P<.001)$. As expected, no significant effect is determined by agreeableness on perceived quality and conscientiousness on trust. All of the variance of the personality traits is mediated by trust and perceived quality, and the model explains 65 percent of the variance in publishing intentions combined (intention OA $\mathrm{R}^{2}=0.35$; intention non-OA $\mathrm{R}^{2}=0.30$ ). ${ }^{49}$

\section{Discussion and Conclusions}

The conceptual framework is based on a personality-attitude-intention/behavior framework with inspiration from research investigating perceived quality, trust-processing, and publishing in a digital environment. ${ }^{50}$ Overall, the model is found to perform adequately with the exception of some of the reverse-scored items.

This study extends the existing literature that investigates publishing intentions in several ways. First, the results confirm, perhaps not surprisingly, that when researchers believe OA journals and articles are trustworthy and reliable, it enhances the intention to publish OA. Although hypothesized, the finding that trust negatively impacts the intention to publish non-OA is perhaps not as easily interpreted. The results suggest that trust not only is key to increased OA use, but also adversely influences non-OA publishing. Perceived quality shows a similar pattern, albeit with the opposite effect. When considering variables such as the impact factor and the perceived overall quality of a journal, it enhances intention to publish via non-OA while simultaneously weakening intention to publish via OA.

The total variance explained in intention $\left(R^{2}=0.65\right)$ exceeds that of comparative studies and establishes that employing a dual measure of publishing intentions provides a major increase in explanatory power. For example, Dulle and Minishi-Majanja and Khalili and 
Singh report similar, albeit somewhat lower, variance explained in intention to publish OA compared to the present study $\left(R^{2}=0.27\right.$, and $R^{2}=0.24$, respectively $) \cdot{ }^{51}$ In their studies, a significant proportion remains unexplained, and whether intention to publish non-OA articles accounts for a large or small part of the remainder of the variance is unknown.

Several previous studies have determined that trust is a major influence on intention to use information technology or an information service, including scientific. ${ }^{52}$ Trust is found to be particularly important in situations involving risk and uncertainty, which, unfortunately, is still the case with OA publishing, likely due to the practices and prevalence of predatory publishers. This study provides evidence that moving past this initial threshold of distrust not only has a positive effect on the intention to publish via OA, it simultaneously weakens the intention to publish by traditional means. This is in line with previous findings, which suggest that experience leads to familiarity, which in turn strengthens intention. ${ }^{53}$ Accordingly, improving trust may be considered pivotal in accelerating OA publishing.

As expected, we confirm that perceived quality - when measured by impact factor, status, and overall quality - is more closely associated with intending to use traditional rather than OA publishing. It has previously been suggested that the quality, status, and prestige of a journal is, among other things, closely associated with how long it has been operational-presumably the longer the better. ${ }^{54}$ As a consequence, newer additions to the publishing industry may be perceived to provide content of lesser quality, although this may vary by discipline. The uncertainty and wariness concerning online journals is further perpetuated by the confusion surrounding predatory publishers, article processing charges, and quality of peer review - which subsequently taint the OA publishing model in general..$^{55}$

Furthermore, Xia reports that it can be viewed as disadvantageous for one's career development to publish in OA journals. ${ }^{56}$ Our findings may be interpreted in light of these assumptions, and it further explains why perceptions of quality are negatively associated with OA but not with traditional publishing. It appears that perceptions of what constitutes quality are closely linked to a traditional publishing model. Even though OA has been around for more than a decade and awareness of it is increasing, it has still not achieved the level of trust and prestige necessary to compete with the primary model for research dissemination. ${ }^{57}$

In summary, the main contribution of this study is the evidence that both trust and quality interact differently with intention to publish in OA versus non-OA journals, specifically increasing one while decreasing the other. There are several implications of these findings. First, researchers seem poised to shift their publishing practices toward OA; trust, however, appears to be pivotal in succeeding with this. Furthermore, our results imply that, if institutions (and policy makers) can work with perceptions of impact factor, and how status is earned (thus influencing perceptions of quality as well), it might be possible to increase intention to publish OA. If the goal is to move toward a publishing model that ensures openness, it is a stark reminder of how much remains to be done when perceptions of quality are positively related only to traditional (non-OA) publishing.

\section{The Influence of Agreeableness and Conscientiousness}

We contribute to the scholarly literature on publishing behavior by testing how individual personality traits influence intentional antecedents. Historically, most studies investigating researcher personality look at its influence on creativity and research production, work satisfaction, or researcher/nonresearcher differences and similarities. Not many examine whether and how these factors influence trust and quality, subsequently guiding intentions. Our findings support the assertion that personality traits not necessarily associated with research production do in fact influence the 
precursors of publishing intentions. Our results show that the individual personality traits of agreeableness and conscientiousness directly affect trust and perceived quality, respectively. An important facet of agreeableness is being trustful. ${ }^{58} \mathrm{OA}$ is considered by many a public good and a fair way to share research. Our findings suggest that a certain personality type may be especially important in influencing the intention to adopt this publishing model.

Previously, we highlighted that agreeable people are trusting, tend to focus more on positive aspects of a new technology, and are more inclined to share knowledge..$^{59}$ When considering a relatively novel, and often criticized, method for disseminating research such as OA, these factors are crucial. ${ }^{60}$ Researchers in our study are highly conscientious, a finding that supports the broader personality literature, while contrasting with some previous studies. ${ }^{61}$

Conscientious individuals strive for achievement, an aspect that is central to this personality trait. Conscientious researchers set clear goals, are cautious, and have long-term plans, suggesting they are in some instances less inclined to engage in risk-taking behavior. ${ }^{62}$ Given that, for many, publishing through OA is still perceived as somewhat uncertain-especially in relation to securing promotion, funding, and tenure-it is perhaps not insurmountable to accept that the safest route for a conscientious individual is the traditional option.

Personality is to some extent plastic, although the main characteristics of one's personality profile remain fairly stable over time. ${ }^{63}$ This suggests that people respond to influence as a function of their personalities. In light of our findings, this implies that influencing highly agreeable researchers works differently from influencing highly conscientious researchers. For example, if we want to move toward increased OA, information that resonates with agreeable researchers will likely be trust-related, while conscientious researchers must be convinced by focusing on their perceptions and attitudes about quality.

\section{Limitations and Future Research}

There are some limitations that should be addressed. First, the study is based on a small sample of researchers from one Norwegian university, potentially preventing any generalization of the results to a larger population. Furthermore, we rely entirely on self-reporting in data collection, and the problems accompanying this method are evident in the number of respondents having to be removed from further analysis due to anomalous response patterns. Third, we acknowledge that the factors contributing to quality assessments of journals are far more plentiful than those described in this study. ${ }^{64}$ The choice of using impact factor, status, and quality was a matter of selecting global criteria that are associated with journal selection. However, future studies can address this limitation by expanding the number of indicators in pretesting to arrive at a superior measure of perceived quality.

Similarly, the poor performance of the reversed personality items highlights a major drawback of using short scales to reduce time expenditure. ${ }^{65}$ Based on these findings, we recommend that a more comprehensive personality measure, such as the 44-item Big Five Inventory, be employed in future studies. ${ }^{66}$ Furthermore, this study does not assess whether perceptions of quality and trust are different for OA journals published by traditional publishing houses, or for journals that have moved from a subscriptionbased model to full OA, which could be a fruitful venue to further explore. Finally, this study does not describe, or measure, how incentive systems - such as awarding funds based on publishing in ranked journals - influence publishing behavior. However, we acknowledge that, at least for Norway, where this study was conducted, the incentive system plays a major part in influencing publishing trends. Thus, another fruitful venue for future studies could be the investigation of how internal and external motivational factors influence publishing intention and behavior. 


\section{Appendix A. Questionnaire}

- Age:

- Gender:

\begin{tabular}{|c|c|c|c|c|c|c|c|}
\hline Statement & & & & & & & \\
\hline \multicolumn{8}{|c|}{ Intention to publish Open Access } \\
\hline $\begin{array}{l}\text { My goal is to submit } \\
\text { the majority of my } \\
\text { future research } \\
\text { articles to open access } \\
\text { journals. }\end{array}$ & $\begin{array}{l}\text { 1. Strongly } \\
\text { disagree }\end{array}$ & 2 & 3 & 4 & 5 & 6 & $\begin{array}{l}\text { 7. Strongly } \\
\text { agree }\end{array}$ \\
\hline $\begin{array}{l}\text { I intend to do what } \\
\text { I can to submit the } \\
\text { majority of my future } \\
\text { research articles to } \\
\text { open access journals. }\end{array}$ & $\begin{array}{l}\text { 1. Strongly } \\
\text { disagree }\end{array}$ & 2 & 3 & 4 & 5 & 6 & $\begin{array}{l}\text { 7. Strongly } \\
\text { agree }\end{array}$ \\
\hline \multicolumn{8}{|c|}{ Intention to publish non-Open Access } \\
\hline $\begin{array}{l}\text { I plan to submit the } \\
\text { majority of my future } \\
\text { research articles to } \\
\text { non-open access } \\
\text { journals. }\end{array}$ & $\begin{array}{l}\text { 1. Definitely } \\
\text { do not }\end{array}$ & 2 & 3 & 4 & 5 & 6 & $\begin{array}{l}\text { 7. Definitely } \\
\text { do }\end{array}$ \\
\hline $\begin{array}{l}\text { My goal is to submit } \\
\text { the majority of my } \\
\text { future research articles } \\
\text { to non-open access } \\
\text { journals }\end{array}$ & $\begin{array}{l}\text { 1. Strongly } \\
\text { disagree }\end{array}$ & 2 & 3 & 4 & 5 & 6 & $\begin{array}{l}\text { 7. Strongly } \\
\text { agree }\end{array}$ \\
\hline \multicolumn{8}{|l|}{ Trust } \\
\hline $\begin{array}{l}\text { In general, I am } \\
\text { confident the articles } \\
\text { published in open } \\
\text { access journals are } \\
\text { trustworthy. }\end{array}$ & $\begin{array}{l}\text { 1. Strongly } \\
\text { disagree }\end{array}$ & 2 & 3 & 4 & 5 & 6 & $\begin{array}{l}\text { 7. Strongly } \\
\text { agree }\end{array}$ \\
\hline $\begin{array}{l}\text { I would assume most } \\
\text { open access journals } \\
\text { are honest. }\end{array}$ & $\begin{array}{l}\text { 1. Strongly } \\
\text { disagree }\end{array}$ & 2 & 3 & 4 & 5 & 6 & $\begin{array}{l}\text { 7. Strongly } \\
\text { agree }\end{array}$ \\
\hline $\begin{array}{l}\text { Overall, articles } \\
\text { published in non-open } \\
\text { access journals are } \\
\text { more reliable than } \\
\text { articles published in } \\
\text { open access journals. }\end{array}$ & $\begin{array}{l}\text { 1. Strongly } \\
\text { disagree }\end{array}$ & 2 & 3 & 4 & 5 & 6 & $\begin{array}{l}\text { 7. Strongly } \\
\text { agree }\end{array}$ \\
\hline \multicolumn{8}{|c|}{$\begin{array}{l}\text { Perceived quality. (Please state to which degree the following factors are important when } \\
\text { choosing where to publish your research articles) }\end{array}$} \\
\hline $\begin{array}{l}\text { Publishing (in journal) } \\
\text { will give me high status. }\end{array}$ & $\begin{array}{l}\text { 1. Very } \\
\text { unimportant }\end{array}$ & 2 & 3 & 4 & 5 & 6 & $\begin{array}{l}\text { 7. Very } \\
\text { important }\end{array}$ \\
\hline $\begin{array}{l}\text { Impact factor of } \\
\text { journal. }\end{array}$ & $\begin{array}{l}\text { 1. Very } \\
\text { unimportant }\end{array}$ & 2 & 3 & 4 & 5 & 6 & $\begin{array}{l}\text { 7. Very } \\
\text { important }\end{array}$ \\
\hline
\end{tabular}




\begin{tabular}{|c|c|c|c|c|c|c|c|}
\hline $\begin{array}{l}\text { Perceived quality of } \\
\text { journal. }\end{array}$ & $\begin{array}{l}\text { 1. Very } \\
\text { unimportant }\end{array}$ & 2 & 3 & 4 & 5 & 6 & $\begin{array}{l}\text { 7. Very } \\
\text { important }\end{array}$ \\
\hline \multicolumn{8}{|c|}{ Agreeableness. (I see myself as someone who...) } \\
\hline $\begin{array}{l}\text { Is sometimes rude to } \\
\text { others }\end{array}$ & $\begin{array}{l}\text { 1. Strongly } \\
\text { disagree }\end{array}$ & 2 & 3 & 4 & 5 & 6 & $\begin{array}{l}\text { 7. Strongly } \\
\text { agree }\end{array}$ \\
\hline Has a forgiving nature & $\begin{array}{l}\text { 1. Strongly } \\
\text { disagree }\end{array}$ & 2 & 3 & 4 & 5 & 6 & $\begin{array}{l}\text { 7. Strongly } \\
\text { agree }\end{array}$ \\
\hline $\begin{array}{l}\text { Is considerate and kind } \\
\text { to almost everyone }\end{array}$ & $\begin{array}{l}\text { 1. Strongly } \\
\text { disagree }\end{array}$ & 2 & 3 & 4 & 5 & 6 & $\begin{array}{l}\text { 7. Strongly } \\
\text { agree }\end{array}$ \\
\hline \multicolumn{8}{|l|}{ Conscientiousness } \\
\hline Does a thorough job & $\begin{array}{l}\text { 1. Strongly } \\
\text { disagree }\end{array}$ & 2 & 3 & 4 & 5 & 6 & $\begin{array}{l}\text { 7. Strongly } \\
\text { agree }\end{array}$ \\
\hline Tends to be lazy & $\begin{array}{l}\text { 1. Strongly } \\
\text { disagree }\end{array}$ & 2 & 3 & 4 & 5 & 6 & $\begin{array}{l}\text { 7. Strongly } \\
\text { agree }\end{array}$ \\
\hline Does things efficiently & $\begin{array}{l}\text { 1. Strongly } \\
\text { disagree }\end{array}$ & 2 & 3 & 4 & 5 & 6 & $\begin{array}{l}\text { 7. Strongly } \\
\text { agree }\end{array}$ \\
\hline
\end{tabular}

Notes

1. Peter Suber, Open Access (MIT Press Essential Knowledge, 2012).

2. Anthony Watkinson et al., "Changes in the Digital Scholarly Environment and Issues of Trust: An Exploratory, Qualitative Analysis," Information Processing \& Management 52, no. 3 (2016): 446-58; Sarah Beaubien and Max Eckard, "Addressing Faculty Publishing Concerns with Open Access Journal Quality Indicators," Journal of Librarianship and Scholarly Communication 2, no. 2 (2014): 1-11.

3. Carol Tenopir et al., "Trustworthiness and Authority of Scholarly Information in a Digital Age: Results of an International Questionnaire," Journal of the Association for Information Science and Technology 67, no. 10 (2015): 2344-61; Jeffrey Beall, "Criteria for Determining Predatory OpenAccess Publishers," Scholarly Open Access (2015); Beaubien and Eckard, "Addressing Faculty Publishing Concerns."

4. Bo-Christer Bjork and David Solomon, "Open Access Versus Subscription Journals: A Comparison of Scientific Impact," BMC Medicine 10, no. 1 (2012): 1-10.

5. Maya Grosul and Gregory J. Feist, "The Creative Person in Science," Psychology of Aesthetics, Creativity, and the Arts 8, no. 1 (Feb 2014): 30-43; John W. Lounsbury et al., "An Investigation of the Personality Traits of Scientists versus Nonscientists and Their Relationship with Career Satisfaction," RED Management 42, no. 1 (2012): 47-59; Sarv Devaraj, Robert F. Easley, and J. Michael Crant, "How Does Personality Matter? Relating the Five-Factor Model to Technology Acceptance and Use," Information Systems Research 19, no. 1 (2008): 93-105; Tao Zhou and Yaobin $\mathrm{Lu}$, "The Effect of Personality Traits on Mobile Commerce User Acceptance," International Journal of Human-Computer Interaction 27, no. 6 (2011): 545-61.

6. Frankwell W. Dulle and M.K. Minishi-Majanja, "The Suitability of the Unified Theory of Acceptance and Use of Technology (UTAUT) Model in Open Access Adoption Studies," Information Development 27, no. 1 (2011): 32-45; Leila Khalili and Diljit Singh, "Factors Influencing Acceptance of Open Access Publishing among Medical Researchers in Iran," Libri 62, no. 4 (2012): 336-54.

7. Rex B. Kline, Principles and Practice of Structural Equation Modeling (New York: Guilford Press, 2011).

8. Dulle and Minishi-Majanja, "The Suitability of the Unified Theory of Acceptance"; Khalili and Singh, "Factors Influencing Acceptance of Open Access Publishing"; Mohamad N. Masrek and Muhammad S. Yaakub, "Intention to Publish in Open Access Journal: The Case of Multimedia University Malaysia," Procedia-Social and Behavioral Sciences 174 (2015): 3420-27; Ji-Hong Park, "Motivations for Web-Based Scholarly Publishing: Do Scientists Recognize Open Availability as an Advantage?" Journal of Scholarly Publishing 40, no. 4 (2009): 343-69.

9. Martin Fishbein and Icek Ajzen, Predicting and Changing Behavior: The Reasoned Action Approach (New York: Taylor \& Francis, 2010).

10. Christopher J. Armitage and Mark Conner, "Efficacy of the Theory of Planned Behaviour: A Meta-Analytic Review," British Journal of Social Psychology 40, no. 4 (2001): 471-99; Paschal 
Sheeran, "Intention-Behavior Relations: A Conceptual and Empirical Review," European Review of Social Psychology 12, no. 1 (2002): 1-36.

11. Dulle and Minishi-Majanja, "The Suitability of the Unified Theory of Acceptance"; Khalili and Singh, "Factors Influencing Acceptance of Open Access Publishing."

12. Tenopir et al., "Trustworthiness and Authority of Scholarly Information in a Digital Age."

13. Kari Kelton, Kenneth R. Fleischmann, and William A. Wallace, "Trust in Digital Information," Journal of the American Society for Information Science and Technology 59, no. 3 (2008): 363-74.

14. Linda V. Knight and Theresa A. Steinbach, "Selecting an Appropriate Publication Outlet: A Comprehensive Model of Journal Selection Criteria for Researchers in a Broad Range of Academic Disciplines," International Journal of Doctoral Studies 3 (2008): 59-79.

15. Watkinson et al., "Changes in the Digital Scholarly Environment and Issues of Trust."

16. Johan Bollen, Marko A. Rodriquez, and Herbert Van de Sompel, "Journal Status," Scientometrics 69, no. 3 (2006): 669-87.

17. Oliver P. John, Richard W. Robins, and Lawrence A. Pervin, Handbook of Personality: Theory and Research (New York: Guilford, 2008).

18. Gregory J. Feist, "A Meta-Analysis of Personality in Scientific and Artistic Creativity," Personality and Social Psychology Review 2, no. 4 (1998): 290-309; Lewis R. Goldberg, "An Alternative Description of Personality: The Big-Five Factor Structure," Journal of Personality and Social Psychology 59, no. 6 (1990): 1216-29.

19. Goldberg, "An Alternative Description of Personality: The Big-Five Factor Structure."

20. Tim Barnett, Allison W. Pearson, Rodney Pearson, and Franz W. Kellermanns, "Five-Factor Model Personality Traits as Predictors of Perceived and Actual Usage of Technology," European Journal of Information Systems 24, no. 4 (2015): 374-90.

21. A. Vedel, "The Big Five and Tertiary Academic Performance: A Systematic Review and Meta-Analysis," Personality and Individual Differences 71 (Dec. 2014): 66-76.

22. Stefanie E. Warlick and K.T. Vaughan, "Factors Influencing Publication Choice: Why Faculty Choose Open Access," Biomedical Digital Libraries 4, no. 1 (2007): 1-12; Watkinson et al., "Changes in the Digital Scholarly Environment and Issues of Trust."

23. Roger C. Mayer, James H. Davis, and F. David Schoorman, "An Integrative Model of Organizational Trust," Academy of Management Review 20, no. 3 (1995): 709-34.

24. David Gefen, "Reflections on the Dimensions of Trust and Trustworthiness among Online Consumers," SIGMIS Database: The Database for Advances in Information Systems 33, no. 3 (2002): 38-53.

25. Per O. Seglen, "Why the Impact Factor of Journals Should Not Be Used for Evaluating Research," BMJ: British Medical Journal 314, no. 7079 (1997): 498-502.

26. Arturo Casadevall and Ferric C. Fang, "Causes for the Persistence of Impact Factor Mania," MBio 5, no. 2 (2014): 1-6.

27. Jerome K. Vanclay, "Impact Factor: Outdated Artefact or Stepping-Stone to Journal Certification?" Scientometrics 92, no. 2 (2012): 211-38.

28. Tenopir et al., "Trustworthiness and Authority of Scholarly Information in a Digital Age."

29. Casadevall and Fang, "Causes for the Persistence of Impact Factor Mania."

30. Murray R. Barrick, Michael K. Mount, and Timothy A. Judge, "Personality and Performance at the Beginning of the New Millennium: What Do We Know and Where Do We Go Next?" International Journal of Selection and Assessment 9, nos. 1/2 (2001): 9-30; Feist, "A Meta-Analysis of Personality in Scientific and Artistic Creativity."

31. Casadevall and Fang, "Causes for the Persistence of Impact Factor Mania."

32. Feist, "A Meta-Analysis of Personality in Scientific and Artistic Creativity."

33. Lounsbury et al., "An Investigation of the Personality Traits of Scientists versus Nonscientists."

34. Zhou and Lu, "The Effect of Personality Traits on Mobile Commerce User Acceptance."

35. Goldberg, "An Alternative Description of Personality: The Big-Five Factor Structure."

36. Chih-Chien Wang and Yann-Jy Yang, "Personality and Intention to Share Knowledge: An Empirical Study of Scientists in an R\&D Laboratory," Social Behavior and Personality: An International Journal 35, no. 10 (2007): 1427-36; Devaraj et al., "How Does Personality Matter?"

37. Zhou and Lu, "The Effect of Personality Traits on Mobile Commerce User Acceptance."

38. Barnett et al., "Five-Factor Model Personality Traits."

39. Fishbein and Ajzen, Predicting and Changing Behavior.

40. D. Harrison McKnight, Vivek Choudhury, and Charles Kacmar, "Developing and Validating Trust Measures for E-Commerce: An Integrative Typology," Information Systems Research 13, no. 3 (2002): 334-59.

41. Masrek and Yaakub, "Intention to Publish in Open Access Journal"; Park, "Motivations for Web-Based Scholarly Publishing"; Warlick and Vaughan, "Factors Influencing Publication Choice." 
42. Vanclay, "Impact Factor."

43. Frieder R. Lang et al., "Short Assessment of the Big Five: Robust across Survey Methods except Telephone Interviewing," Behavior Research Methods 43, no. 2 (2011): 548-67; Goldberg, "An Alternative Description of Personality."

44. Lang et al., "Short Assessment of the Big Five"; Goldberg, "An Alternative Description of Personality."

45. Scott B. MacKenzie, "Opportunities for Improving Consumer Research through Latent Variable Structural Equation Modeling," Journal of Consumer Research 28, no. 1 (2001): 159-66.

46. Michael W. Browne and Robert Cudeck, "Alternative Ways of Assessing Model Fit," Sociological Methods \& Research 21, no. 2 (1992): 230-58.

47. Ibid.

48. Claes Fornell and David F. Larcker, "Structural Equation Models with Unobservable Variables and Measurement Error: Algebra and Statistics," Journal of Marketing Research 18, no. 3 (1981): 382-88.

49. Reuben M. Baron and David A. Kenny, "The Moderator-Mediator Variable Distinction in Social Psychological Research: Conceptual, Strategic, and Statistical Considerations," Journal of Personality and Social Psychology 51, no. 6 (1986): 1173-82.

50. Barnett et al., "Five-Factor Model Personality Traits"; Fishbein and Ajzen, Predicting and Changing Behavior; Goldberg, "An Alternative Description of Personality"; Zhou and Lu, "The Effect of Personality Traits on Mobile Commerce User Acceptance"; Knight and Steinbach, "Selecting an Appropriate Publication Outlet"; Kelton et al., "Trust in Digital Information"; Tenopir et al., "Trustworthiness and Authority of Scholarly Information in a Digital Age."

51. Dulle and Minishi-Majanja, "The Suitability of the Unified Theory of Acceptance"; Khalili and Singh, "Factors Influencing Acceptance of Open Access Publishing."

52. Gefen, "Reflections on the Dimensions of Trust and Trustworthiness among Online Consumers"; McKnight et al., "Developing and Validating Trust Measures for E-Commerce"; Nicholas, D., Watkinson, A., Volentine, R., Allard, S., Levine, K., Tenopir, C., \& Herman, E. (2014), "Trust and Authority in Scholarly Communications in the Light of the Digital Transition: Setting the Scene for a Major Study," Learned Publishing, 27(2), 121-134; Watkinson et al., "Changes in the Digital Scholarly Environment and Issues of Trust."

53. Jingfeng Xia, "A Longitudinal Study of Scholars Attitudes and Behaviors toward OpenAccess Journal Publishing," Journal of the American Society for Information Science and Technology 61, no. 3 (2010): 615-24.

54. Peter Suber, "Open Access to the Scientific Journal Literature," Journal of Biology 1, no. 1 (2002): $1-3$.

55. Jeffrey Beall, "Predatory Publishers Are Corrupting Open Access," Nature 489, no. 7415 (2012): 179 .

56. Wilhelm Peekhaus and Nicholas Proferes, "How Library and Information Science Faculty Perceive and Engage with Open Access," Journal of Information Science 41, no. 5 (2015): 640-61.

57. Xia, "A Longitudinal Study of Scholars Attitudes and Behaviors."

58. Goldberg, "An Alternative Description of Personality."

59. Zhou and Lu, "The Effect of Personality Traits on Mobile Commerce User Acceptance"; Devaraj et al., "How Does Personality Matter?"; Wang and Yang, "Personality and Intention to Share Knowledge."

60. Aspasia Togia and Stella Korobili, "Attitudes towards Open Access: A Meta-Synthesis of the Empirical Literature," Information Services \& Use 34, no. 3/4 (2014): 221-31.

61. John et al., Handbook of Personality; Lounsbury et al., "An Investigation of the Personality Traits of Scientists versus Nonscientists."

62. John et al., Handbook of Personality; Lewis R. Goldberg, "The Development of Markers for the Big-Five Factor Structure," Psychological Assessment 4, no. 1 (1992): 26-42; Bruno Chauvin, Danièle Hermand, and Etienne Mullet, "Risk Perception and Personality Facets," Risk Analysis 27, no. 1 (2007): 171-85.

63. John et al., Handbook of Personality.

64. Togia and Korobili, "Attitudes towards Open Access"; Vanclay, "Impact Factor."

65. Gregory T. Smith, Denis M. McCarthy, and Kristen G. Anderson, "On the Sins of ShortForm Development," Psychological Assessment 12, no. 1 (2000): 102-11.

66. Oliver P. John, Eileen M. Donahue, and Robert L. Kentle, The Big Five Inventory - Versions 4a and 54 (Berkeley: University of California, Berkeley, Institute of Personality and Social Research, 1991). 